\title{
Proposing a methodology for the operationalisation of Multiple Streams Approach, using the Inner-City Technology Colleges as an empirical example
}

\section{Flores, I;}

\begin{abstract}
In this paper, we argue that there is a need for the streams to be ripe at the moment of legislation approval to increase the probability of policy implementation. We developed a model of analysis that applies MSA, departing from a qualitative approach we purpose an empirical mathematical model which allows policy makers to evaluate the probability of successful implementation, given the variables available at decision moment. The contribution of this paper is to inform policy makers on the need to work towards policy acceptance, reducing the rate of non-enactment and legislative inefficiency.

We applied the model to the case of public private partnerships in education (ePPPs), using the Inner City Technology Colleges, which was the first attempt to create ePPPs by Margaret Thatcher in 1986. We conclude that the reason for implementation failure lies on the lack of balance between the streams, who were not ripe at the time of legislation.
\end{abstract}

Keywords: Public private partnerships, education, multiple streams approach, school administration, England, Neoliberalism; Inner City Technology Colleges

\section{Introduction}

In this paper, we argue that there is a need for the streams to be ripe at the moment of legislation approval to increase the probability of policy implementation. For this purpose, and considering the optimization of public policy decision, we use Multiple Streams Approach (MSA) to argue that policies which enactment depend on the acceptance by several actors, such as investors, school managers, teachers and parents, need to benefit from wide support and stream ripeness at the moment of policy discussion and legislation.

We developed a model of analysis that applies MSA, departing from a qualitative approach we purpose an empirical mathematical model which allows policy makers to evaluate the probability of successful implementation, given the variables available at decision moment. The contribution of this paper is to inform policy makers on the need to work towards policy acceptance, reducing the rate of non-enactment and legislative inefficiency. 
We applied the model to the case of public private partnerships in education (ePPPs), using the Inner City Technology Colleges, which was the first attempt to create ePPPs by Margaret Thatcher in 1986. Those were the years where shrinking the state was a popular political trend, but not in education where the sate ended up with more concentric power, despite the launching of first ePPPs legislation. We conclude that the reason for such failure lies on the lack of balance between the streams, who were not ripe at the time of legislation. Private investors were not motivated towards education as a business, parents, teachers and directors had not understood the scope of the policy and policy entrepreneurs were diffuse and weak. These circumstances outbalance the ideological strength of a Neoliberal government with parliamentary power to legislate and purpose change.

In part one, we engage in a discussion of what literature has said about the ePPP policies of the period under consideration and why it is relevant that we apply a different set of lens to analyse the policy process from a different angle. In part two, we introduce the reader to Multiple Streams Approach (MSA) and to the methodology developed by the authors, both qualitative and quantitative and in part three we apply our model of research to test the hypothesis, that if the streams are not balanced at the legislative moment the probability of successful enactment is reduced. Part four sums up our conclusions and opens new research questions.

The literature on decision making of Public Private Partnerships in Education

Public-private partnerships can be explained using several sets of lenses, or theoretical approaches, this theme as been vastly studied both in education and in other adjacent areas. Public Choice theories have been vastly used to address the roll back of the state, This model is, nevertheless, unable to answer why do countries privatise some sectors and don't follow the same rule for other sectors (Zahariadis, 1995). It focusses on the problem but it does not provide any means of explaining why the governments keep some economic areas for themselves. Welfare areas are the biggest employers in most OECD economies, so according to these believes they should be on the list to be privatised and this is far from happening everywhere, including in countries where governments are strongly pro-market. "Straightforward application of economic theory to study education and the education market while designing education policies is fraught with many pitfalls. While attaining efficiency in resource use and competitiveness are the dominant concerns for policymakers in the emerging global knowledge economy, inclusive and socially cohesive growth also deserves prime attention 
from policymakers" (Chattopadhyay, 2012, pp 5).

Though we haven't found any study targeted at explaining ePPPs using this theory, there are some studies in satellite areas, that expose the flaws of this theory to explain contemporary policy making. In a philosophical article on how democracy loses when education is seen as a public choice commodity Lauder (1991) argues against public choice and neo-liberal theories in understanding political decisions, especially in a complex field such as education. Public choice can explain the beginning of the education movement in England (Mangset, Kleppe, \& Røyseng, 2013) though it fails to explain its evolution and specially the recent consolidation. We argue that it cannot explain why implementation failed during the conservative period.

In a recent work Verger and colleagues (2016) argued that the English process of school privatization was strongly anchored in a strong hegemony of neoliberal principles. Though it is clearly so, this argument fails in explaining why it took so long, and how could this policy fail to be implemented during the most fierce neoliberal years. The governing party perspectives has been exploited by West $(2014 ; 2013)$ in relation to the English case concluding that neoliberal ideas and government political colours are far from the determinant variables in the process of school management changes. So, they call for other studies and other insights into this process. Though we ascertain that ideas matter, and that the governing party privileges some policies over others, the trouble is that this is just one variable within a set of several variables that will be considered and included in the model adopted to answer the question.

Associated to the government in power, comes the ideas of welfare state regimes. The classification proposed by Esping-Andersen (1990) where the states are divided in clustered typologies is also an obvious attempt to explain privatisation movements. Each set of countries is characterised by a specific institutional and social framework that act as a mould to the adoption of certain policies or socio-political trends. In this classification, there is a clear distinction between: (i) liberal states; (ii) social democratic countries; (iii) conservative welfare regimes and (iv) south European countries.

This theory has been put to test as a powerful set of lenses to analyse ePPPs (Klitgaard, 2007) in a comparative case study research, where Klitgaard looked at the USA (representing a liberal economy), Sweden (representing a social democratic country) and Germany as a conservative welfare state. He set the hypothesis that assumed the biggest trend to privatisation should come from the USA, Sweden should be immune to this type of trend, though it should embark on changes that evolved parents and community, and Germany should totally resist this type of trend. His research made it clear that the clustering of countries according to the welfare benefit theory leads to no conclusion. There is no correlation between country typology and 
changes in education organization.

In the 1990s some authors targeted decision making in education, trying to understand why some governments can more efficiently turn ideas into legislation, while other governments seem to promote the same ideas for long periods of time without any success, through institutional lenses. Thelen (2004)in a study about Germany's vocational education noticed that political decisions are not decisions made at one exclusive point in time, most policies need successive votes from several institutions in the chain of decision, this are obviously the veto points at work. She also argues, that institutions can be so strong that even following major disruptive events, such as wars, they find a manner of re-implementing old policies again and again, working as a barrier to any type of change. Thelen's work shows the strength of this theory in explaining why things do not change, but it fails in enlightening change.

In 2010, Klitgaard (2010)revisited the voucher subject using institutionalism theories to access the differences in primary school voucher options, using the USA and Sweden as empirical cases. The explanation found for the universal voucher system in Sweden versus the limited federal experiences in the USA lies on veto points structure, arguing that in the USA a multitude of veto points act as an impediment for governments to fulfil their preferences. As the different powers haven't been held by the same ideological trend it is very hard to make radical ideas come through the all system. Some state constitutions are more permissive, and have easier modes of decision, that justifies voucher sporadic implementation in a few states. On the other hand, Sweden governments have a formidable autonomy when the majority in parliament is controlled by only one political force, in which case only the unions could act as a veto-point and at the time they did not see voucher programmes as a big threat to their associates, allowing for the measure to move on. The idea of lack of veto points is clearly strong, though it is still insufficient to explain the failure of ePPPs in England during the long conservative power, as the legislation went through (without many veto points) though it was hardly implemented.

Institutional approach is also centred on domestic actors and structures which ends being very limitative to understand the process of private actors in education, once this is very much a global movement, where ideas and influence easily cross borders. Global ideas or world culture theories are also strong candidates for explaining the global adoption of certain lines of policy. Many arguments that lie behind these ideas emerge with a scientific layer and is promoted as good practices and are perceived as effective even though there is lack of evidence on how effective they really are (Robertson \& Verger, 2012). Despite all the recommendations and 
discussions, the reality is that countries take these pressures differently and the change of the systems has been slow and in different directions. A recent study (Alexiadou, Fink-Hafner, \& Lange, 2016) focus on how 'new' EU countries take OMC more seriously than 'old' partners.

The influence of international actors is many times made through informal channels hard to trace: private meetings, summits, conversations, personal relationships and social events. The network structure that is created around the government and decision centres is complex and intricate, as Ball as shown on his studies on interconnections of people and institutions (Ball, 2012).

The book "Global Education Inc.: New Policy Networks and the Neo-Liberal Imaginary" (Exley, Braun, \& Ball, 2011) is very clear in the manner it enlightens the importance of networks and several layers of business and actors that are now present in education structures all over the world, suggesting the beginning of the end of education as a welfare state affair. He shows how a multi-centre net of interests move and connect to change the face of the industry as they gain credibility and legitimacy to do so by supporting their views on international organisations. Therefore, Networks and Global theories are very much interlinked, with the major difference being the that first focus on connections and the second is more interested in the influence of transnational players and implementation of similar solutions all over the world. For Ball, what is emerging is not the privatization of education, but a modality of metagovernance where complexity is immense, making it all very hard to understand to the common citizen and to the actors evolved, as each player has only a small share of knowledge and the full picture becomes blurry. With such a system, it is very difficult to make informed choices and to control what is education at all.

Globalisation, world culture theory, or even network theories stand a point when they identify the important role of international institutions, supra-national, and links among actors in designing and promoting certain lines of action. What this theory cannot answer is why countries answer in such different modes, once they are exposed to the same line of thought and to similar solutions. Therefore, it is important to consider the role of global influence and networks of individuals as other pieces in our model, predominantly at the policy drawing stage with an arm stretched to policy entrepreneurs who make the diffusion and local framing of the policies.

Our idea to understand failure or delay in implementation is to relay on a multiple streams model, where several aspects need to be mobilized for a successful implementation balance. 
Multiple Streams Approach

Multiple Stream Approach (MSA) can bring several sides of policy making together and provide an exhaustive model of analysis, while maintaining the indispensable parsimony. It is also a good model to explain decisions amidst ambiguity, time constraints and strong influences from third parties.

Kingdom (1984), used the Garbage Can Model $^{1}$ to primordially study agenda settings with a three stream model. Basically, the model is very much the same, where 'Garbage Cans' were transformed in independent streams flowing in a serendipity manner, each carrying an aspect of political decision: policy, problems and politics.

The basic idea is that change happens because "choices are looking for problems, issues and feelings looking for decision situations, solutions looking for issues and decision makers looking for work" (Kingdon, 1984) can, in our view, explain complex decision making and policy legislation.

We can therefore look at decision making like a large set of streams where policies, problems and politics float until policy entrepreneurs take content out to be matched, bearing in mind the timing and the needs of the actors to show work and decision capacity. Policy entrepreneurs come in and out of the decision stage, so they are also floating in a stream. Change happens when a problem and policy can be matched, creating a coherent speech that can be accepted by the actors in the politics stream - government. Parliament, Institutions, and society (or national mood). The coupling is proportionated by policy entrepreneurs, that can be individuals or organizations, in or out of the government, who are engaged in having a certain pet policy approved and implemented.

This approach leads into a several variable model (Figura 1), where change is impossible to happen when one of the streams fails, or is not ready to accept change. Each of the streams is independent.

Policy Stream: Contain ideas that are produced as solutions to abstract problems. Most of the policies are developed by people set in institutions that are dissociated from politicians

${ }^{1}$ Garbage Can Theory (Cohen, March, \& Olsen, 1972). This theory has been developed by computer simulation based on empirical studies of "organized anarchies" (Cohen, 1972) which are characterised as organisations that: (i) work based on "a variety of inconsistent and ill-defined preferences", being that these structures end up discovering the best solutions through practice; (ii) the available technology is unclear and the processes are not fully understood by its members; (iii) participants vary in the amount of time and effort they devote to different domains, being that the boundaries of action are uncertain. 
and are a set of ideas that travel from one field to another. Policies can be developed by scholars at universities, by think tanks or by International Organizations. Occasionally policy developers overlap policy entrepreneurs, as the people who developed a certain strategy become attached to it, and gets involved in approval processes. Other times, this people are totally independent of the policy approval or implementation, as a policy was developed for other purposes, or just for theoretical reasoning. Policies to survive and to be appealing for practical application must obey to certain characteristics, that can be adapted and changed. The have to be valued and acceptable for that several policy dimensions should be taken into account at the time of policy design and proposal: (i) feasible from a technical point of view, (ii) the resources involved must be adequate and within the resource constraints, (iii) there must be a network of people involved who support the policy and these people must know what their role is, creating a policy community. (Kingdon, 1984) and (iv) finally there is a need for network integration (Jones et al., 2016) that shape the strength of idea dissemination or extinction.

\section{Figure 1 - Variables consideres in the Multile Streams Approach}

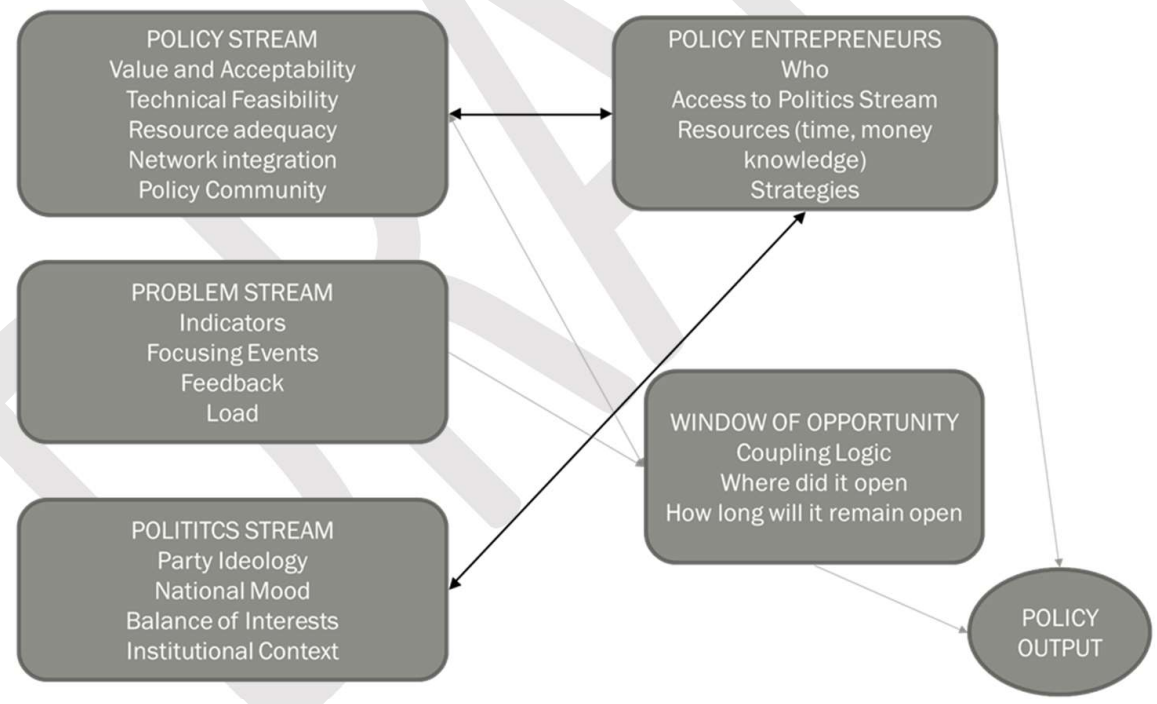

Source 1: Adapted from (Jones et al., 2016)

Problem Stream: are issues perceived as problematic by policy makers, and are brought into need to be solved at a certain point in time. For a problem to be seen as such there is the need for: (i) indicators that are some type of metrics that can be associated with severity of a given problem, many times these indicators do not exist and they are absent or anecdotic. (ii) Alternatively, there can be focusing events that are sudden, such as accidents, they tend to provide powerful impetus for action or change. (iii) Problems can also emerge as a feedback 
mechanism to previous policies that in an attempt to solve a problem create or uncover other. (iv) finally, the load is connected to how many problems are already being dealt with, and if there is the capacity to face a new problem. Sometimes a policy has the ambition to deal with many problems at the same time, especially if none of the problems is well defined.

Politics Stream or Political Stream: In this stream we find the political, institutional, ideological, and cultural. In this stream, we have contemplated the ideology in power, basically divided in two broad areas - right wing conservative governments or left wing socialist governments, for the sake of the policy under study we have considered that a conservative government should increase the probability of policy change towards ePPPs. National Mood is related to the general public opinion towards the policy/problem that is being discussed. Balance of interests is related to the strength positions of actors who are interested in the problem/policy under discussion such unions, associations, and other advocacy groups. Finally Institutional Context is the balance of support or opposition that the policy/problem have to face within the political context, meaning institutions like the parliament or the ministry.

Policy entrepreneurs act as a coupling agents are individuals or organizations who provide the required energy to bring the streams together within a limited period. These people need to have privileged access to decision makers, and need to invest time, knowledge and money to push for their pet solution. They also define strategies to frame the speech in order to make the solution look like the best solution to solve the identified problems.

Window of opportunities 16 Policy Studies Journal, 44:1 MSA posits an idea's survival is related to five key subcomponents within the policy stream. Proposals likely to survive conform to existing value constraints (value acceptability), the technical ability to create and/or implement the proposal is at least a possibility (technical feasibility), and the needed resources for the proposal are obtainable (resource adequacy). Finally, there are the policy communities (Kingdon, 1984) or policy networks (Zahariadis, 1999) associated with the ideas that shape how dissemination along dimensions of size, mode, capacity, and access influence an idea's proliferation or, in some cases, its extinction (network integration).

The Political Stream. The political stream refers to the institutional and cultural context of the agenda or output of concern. This stream is operationalized using three subcomponents. National mood refers to the general orientation of the public toward issues, values, or solutions relevant to the policy problem. Party ideology refers to the aggregate orientation of the political parties within relevant institutions. Balance of interests refers to the aggregate position of relevant interests, including advocacy groups and other actors interested in a particular problem. 
Policy Windows refers to the opportunity that opens to make the moment adequate for policy change. They normally open in the problem or political streams and can be seen as providing the adequate institutional context, opportunities and limitations for the adoption of specific policies. It is composed by the logic of the speech and the amount of information required by the actors before a decision is made (Jones et al., 2016) and it does not remain open for ever. If no decision is taken during a limited period of time, there will be need to wait for a re-opening of the window. The time a window remains open or shut is not known.

Why MSA is adequate for our analysis

This model shows a credible alternative to the mode how institutions muddle through complex and ill-defined decisions. Dealing with unclear social dilemmas is still a reality, therefore, keeping the options open by never choosing a definitive solution is a clever way of moving. The problems are constantly on the stream looking for better matches, seen by different actors with distinct motivations in a renewed period. This line of thought can probably explain why most education concerns are always in the political agendas, and why so many "new strategies" are constantly being implemented, to be changed shortly after by something else that may seem totally disconnected and out of tune "directs the emphasis of policy making on the particular rather than on general policies and their possible coherence" (Peters, 2002).

In the education sector, there is an ill knowledge of the exact problem one wants to tackle. Normally general and diffuse ideas are at stake - increase success, increase equality, better international results, better adjustment to working markets, and so on. Most choices are made by flight or oversight, i.e. other choices are attached to a certain problem but it seems to have no result, therefore changing seems to be a constant need. Problem solving progress is hardly measured, and important choices are not likely to solve problems. When problems are eventually solved it is hard to find a direct link to the choice provided, or which choice made a difference, as several problems tend to be attached to single policies. Or many policies are attached to the same problem.

How the state looks at education depends greatly on: what solutions are in the stream; to which problems these solutions could fit; what are the feelings of the society, when is the best time to act and who are the available participants.

Therefore, if solutions like "public private partnership to manage schools"; "vouchers for choice"; "curricular autonomy" happen to meet problems such as "low performance"; "lack of choice" "freedom"; "lack of efficiency"; "need for flexibility"; "budget constraints", 
"inadequacy to labour markets" in a time when the right actors with the right amount of energy are around, a window of opportunity opens for new choices to substitute previous ones, without previous studies or concerns for future impact. Studies tend to be made later, when coming back is really hard.

As the state boundaries become more blurred, the governing instruments and mechanisms for decision do also become fuzzier and less well structured. Actors move fast, in between many problems and solutions, never holding all the information or being able to see the complete picture. Decisions are more random; therefore, the multiple stream model is also useful to explain this randomness.

Having said all this, the multiple stream model seems a good departing point to analysing the education system, namely in its relation public-private.

Another strand of advantage was the association to computational models, which gave us the inspiration to develop a framework that could lead to the calculus of probability of success. For the building of this logic we have departed from a computer simulation developed by Zahariadis (2003, pp. 126-151), where he suggests that the policy process is sharply interactive, and he purposes a formula to understand quantitatively that policy "choice results from the coupling of the three streams subject to the presence of an entrepreneur and an open window" (pp. 132). The mode we are transforming the computer simulation into an empirical tool is explained in next section, "Methodology of Analysis".

The most critical aspects of this model relate to the fact that initially it was developed only to explain agenda setting, and here we intend to use it to explain policy failure. We are not innovating, as it has been used before to explain why policies were not enacted as expected (Teodorovic, 2008), or why they have perverse effects (Zahariadis \& Exadaktylos, 2016). Our intention is to prove that when a policy is legislated before the streams are ripe and couple at the right moment, they have a low probability of being successfully implemented.

On another side, MSA has been criticized for suggesting that policy is random. Though stream models were developed to introduce dynamics and randomisation to the stage model of analysis (first developed by Lasswell, 1956), showing that the way problems get into the agendas and solutions are an ad-hoc process and do not always come in an organised way, they do not substitute the logical line of analysis that divides the policy process into clear stages as argued by (Howlett, McConell, \& Perl, 2013) “combining the two metaphors - cycles and streams thus has the potential to create a powerful conceptual apparatus". 
Qualitative analysis

The generalist hypothesis that we intend to test is: the probability of policy implementation increases when there is a balance of the streams during the approval period. When a policy is approved before this balance is met, the implementation has smaller chances of success, especially in a type of policy that needs to mobilise several actors before it gets to the field.

The data to be analysed is essentially qualitative and multi-sourced: peer-reviewed papers, legislation, white and green papers, parliamentary discussions, speeches by key stakeholders, electoral manifestos, newspaper articles, published interviews, reports by political parties, unions, think tanks and others on the topic. 


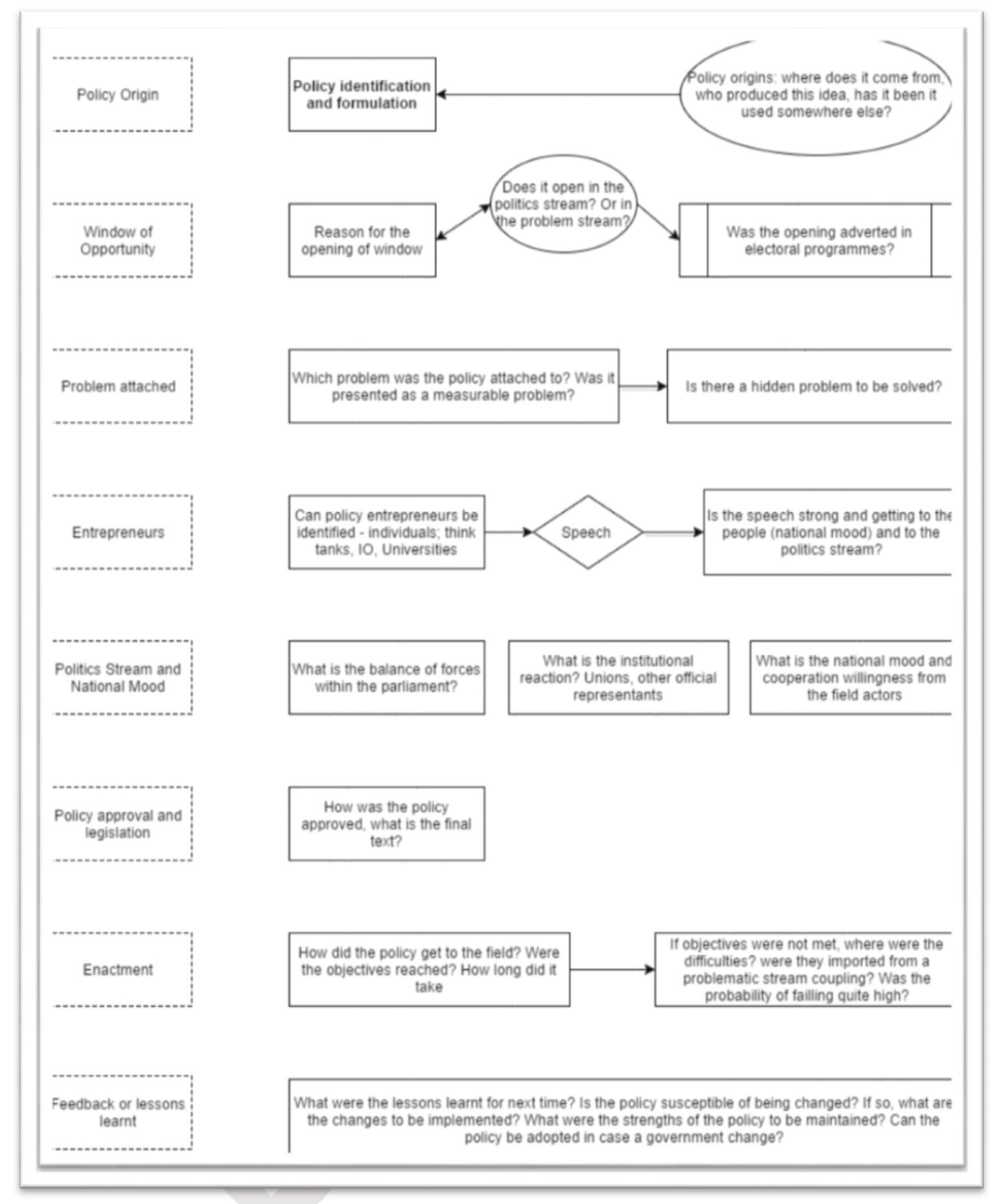

Figure 2 - Logic behind information gathering and organisation (author conception)

To deal with the data we decided to use MaxQda and to develop a codification of variables according to the MSA model. This originated a codebook that allows for the clarification on how to code content according to the understanding of the theory being tested. The variables created a mirror of what the authors of MSA have preconized within each of the streams (Figure 1). 
Once all the documents were coded for the variables in the model we organised the information as shown in the flowchart (Figure 2), showing that there are several steps and actors involved for a policy to be approved. This scheme made it possible to easily identify the weak points of a policy, and intuitively understand why the implementation failed or succeeded.

Our logic of research starts with the identification of the policy origin, and by understanding: (i) where and by whom it was initially purposed, (ii) Whether it has been used before, in the country or somewhere else, (iii) and if so under which concrete formulation. This previous analysis gave us a clearer insight on ideological and philosophical concerns behind each purposed solution. Within this analysis we also studied how was the policy was being presented in its feasibility, resource acceptability, policy community and network integration.

Once the policy origin and design were described we moved on to understand what was the state of the window of opportunity, explaining why and where it had opened, and if the policy under research had been adverted during electoral programmes or any previous event.

The idea that followed was related to the identification of the problem attached, and why it had emerged as a problem in that moment. We searched for indicators, focusing events, the amount of problems that were being mobilized and whether this problem had been uncovered by previous policies.

Step number four was linked to entrepreneurs and their identification, in terms of identity but also in their influence in framing the speech, providing studies, investing their time and money to support their pet policy. The relation between entrepreneurs and decision makers was also analysed, as this is a good measure of entrepreneurs' strength.

We moved on to analyse the pollical stream and all its components, the ideology of the party in the government, the balance of forces within the institutions, the national mood and the position assumed by unions, associations, and other influential organizations.

As we are looking only at policies that were approved, we have engaged in understanding how it was approved, who voted in favour and against, what were the reactions of the parliament and institutions and what was said in the approval text, including objectives and implementation period.

As our evaluation is related to enactment we engaged in the analysis of policy implementation, using the number of schools that had moved into the policies purposed. WE were interested in understanding whether the objectives were achieved, and if not what were 
the lessons to be learnt. We also linked success or failure to the strong/weak points identified in the previous analysis.

Finally, as a starting point for the next policy, the lessons learnt were incorporated in the design of the new scheme proposed, including how well the policy could travel to a new government or a new window of opportunity.

As a result of this analysis we were able to produce a thick policy description, where we really aimed at telling the story of the rise and fall of a certain measure within a limited period of time.

Quantitative analysis

A final methodological approach is related to the quantification of the multiple streams framework, which is an original contribution to methods, on using the qualitative information to test quantitative models.

The challenge is to test the probability statement, therefore I set on transforming the description of each policy into a grid of values to quantify what is the balance required in each stream to increase the probability of success.

Based on previous work where a theoretical quantitative model is suggested (Zahariadis, 2003), we wanted to find a manner to measure the strength of the entrepreneurs, the difficulty of a policy and a problem and to quantify national mood and politics stream.

Mathematical models and simulations are to be used as metaphors and not to determine a single direction or explanation of events. This model will only make any sense if at the end of this research we arrive at meaningfully explanations of reality. We expect to understand the complex decision process and the interaction between actors and society, we want to go slightly further than simply stating that the world is difficult and complicated. The aim of the purposed model is to give snapshots of a constant flux, policy is always moving, exactly like the stream in a river, we hope that our camera is pointed at the interesting occurrence at the several moments of policy progression. The aim of modelling is to purpose and structure a set of assumptions that define what reality can look like, in a manner that can be tested for several scenarios.

For building a systematic approach one needs to identify the characteristics of actors in the system; recognise that leadership does not come solely from the leader, but from an intricate net of connections; accept that decision may be made out of shortcuts to gather information 
that is never complete or true; actors develop their own ways to digest information and decide on its validity; policy is often an experiment and not a tested intervention for solving problems and policies are often reassessed to test for their value, so another one can be tested instead.

The flowchart for policy making can be supported by a computer model, in the line of what has been purposed by the Garbage Can Model and later adapted by Zahariadis (2003) into Multiple Streams Framework. The logic proposed follows Zahariadis on weighs and chance, naturally with some adaptations to fit the layers proposed, a parliamentary system is also an assumption for my model.

The cybernetic model flows with the flowchart proposed where one pair of problem/solution is analysed at a time, decision is taken when the value $(\mathrm{C})$ for Choice is reached or exceeded.

Therefore, a choice process will start when a window of opportunity (W) opens within a favourable political moment (S3), and the policy (S2) and problem (S1) can be coupled by a qualified entrepreneur (S6). The qualified entrepreneur must tame National mood and Institutions (MI) and be quick enough to do all this before the window closes.

$$
C=f[(S 1 * S 2)|(S 6 * M I)|(W * S 3)]
$$

To test the model, we had to give weights to problems, policies, entrepreneurs, National mood and institutions, determine whether the window was open and weight how favourable were the political circumstances. The logic we followed was anchored on Zahariadis previous theoretical work, where small weights mean hard problems. or difficult policies.

S1 - Problem vector - each problem contains a certain amount of information that is known to policy makers. The information available differs from problem to problem, and some problems have been highly studied and there is a lot of information attached to them, while other problems are black boxes, political actors don't know much about their origin or even about their effective existence. Following the same logic as Zahariadis a value of $\{.5 ; .4 ; .3 ; .2\}$ is attached to each problem - problems that we know a lot about have a higher coefficient than problems we do not know much, therefore they are harder to solve.

S2 - Policy vector - follows the same logic each policy contains an amount of information and the range of values is the same $\{.5 ; .4 ; .3 ; .2\}$, meaning that .5 is a policy well tested, feasible and with an assured value, while .2 is a policy with less information load, and eventually harder to implement. 
S3 - Political vector -we considered only two parties (a conservative and a social democratic) who open the window and influence the speech content. Opposition's posture towards the policy was also considered in this vector, the rest of the components have a different weight in the formula, thus they are treated in a different vector MI.

S6 - Entrepreneur vector - it represents entrepreneurs (S3), who can benefit from a certain policy, therefore their role is to pressure for the emergence of their pet policies. They have different resources such as time, access to information, access to decision makers and money. There is a resource attached to entrepreneurs $\{0.2,0.4 ; 0.6 ; 0.8 ; 1\}$ smaller weights signify more skills, i.e. an entrepreneur attached to a smaller weight can solve more difficult problems and implement riskier policies.

MI - National Mood and Institutions - it varies from cautious (0.2) to reckless (1), meaning unfavourable and favourable respectively. The value of national mood and institutions can change depending on political (S3) popularity and the capability of speech articulation by entrepreneurs (S6). These are necessary conditions, though not sufficient, for a policy to be able to move on. National mood and institutions represent an important point for a pair policy/problem to be accepted and approved.

Given all this the propensity for policy change has to combine all the elements above with a very small theoretical propensity (PC - propensity of choice). Given the need for change in education, by the opening of a window within a certain political environment the process starts. It can fail several times from step 3 onwards, which places de capability of the entrepreneurs in the centre of the model. Meaning that the available entrepreneur (drawn from S6) must have a power that matches:

$$
[S 6 \leq(S 1+S 2) *(M I)+S 3] \mid(W)
$$

Theoretically, this equation means that a difficult problem (.2) will only be attached to a difficult policy (.2) by a very skilful entrepreneur (0.4) when both national $\operatorname{mood}(M)$ and institutions (I) are favourable, no policy will be accepted nor implemented in an adverse institutional or national mood set, as veto points will emerge and be unsurpassable at that moment. All of this is subject to the window of opportunity remaining open during this period.

In practice to move from the theoretical model to an empirical analysis, we set on creating indexes for valuing each vector. To create the indexes a list of clear statements was developed where each aspect of the stream is evaluated (Table 1). Though the statements are anchored on 
our specific problem (the emergence of ePPPs) they can be adapted to focus on different issues, where actors, problems and policy have different specifics.

Table 1: Checklist to transform qualitative data into quantitative approach

\begin{tabular}{|c|c|c|c|}
\hline & Policy Name and date & True (1) & $\begin{array}{l}\text { False } \\
(0)\end{array}$ \\
\hline & WINDOW OF OPPORTUNITY & & \\
\hline 1 & The window opened in political stream (Ex. Elections) & & \\
\hline 2 & $\begin{array}{l}\text { There was no reason for a sudden close of the window (ex. } \\
\text { An accident of political upheaval) }\end{array}$ & & \\
\hline 3 & $\begin{array}{l}\text { The government was fast in policy approval (no more than } \\
1 \text { year since the policy first emerged) }\end{array}$ & & \\
\hline & POLITICS STREAM & & \\
\hline 1 & The government was predominantly conservative & & \\
\hline 2 & $\begin{array}{l}\text { The main opposition party did not oppose policy } \\
\text { MI - NATIONAL MOOD AND INSTITUTIONAL } \\
\text { BALANCE }\end{array}$ & & \\
\hline 1 & Parents were generally in favour & & \\
\hline 2 & Teachers, Head teachers from state schools were in favour & & \\
\hline 3 & Teacher Unions did not organise major strikes or parades & & \\
\hline 4 & Local/Regional authorities were favourable & & \\
\hline 5 & No major opposition on the press & & \\
\hline 6 & $\begin{array}{l}\text { Opposition surged mainly from marginal actors } \\
\text { (intellectuals, small pressure groups) }\end{array}$ & & \\
\hline & S1-PROBLEM STREAM & & \\
\hline 1 & There was more than one problem attached to the policy & & \\
\hline 2 & There was an event calling attention to the problem & & \\
\hline 3 & The problem was quantified & & \\
\hline 4 & The problem was well defined & & \\
\hline 5 & $\begin{array}{l}\text { The problem could be recognised as affecting more than } \\
25 \% \text { of students }\end{array}$ & & \\
\hline 6 & The problem affected several social and economic classes & & \\
\hline 7 & There was an urgent problem to be solved & & \\
\hline & S2 - POLICY STREAM & & \\
\hline
\end{tabular}




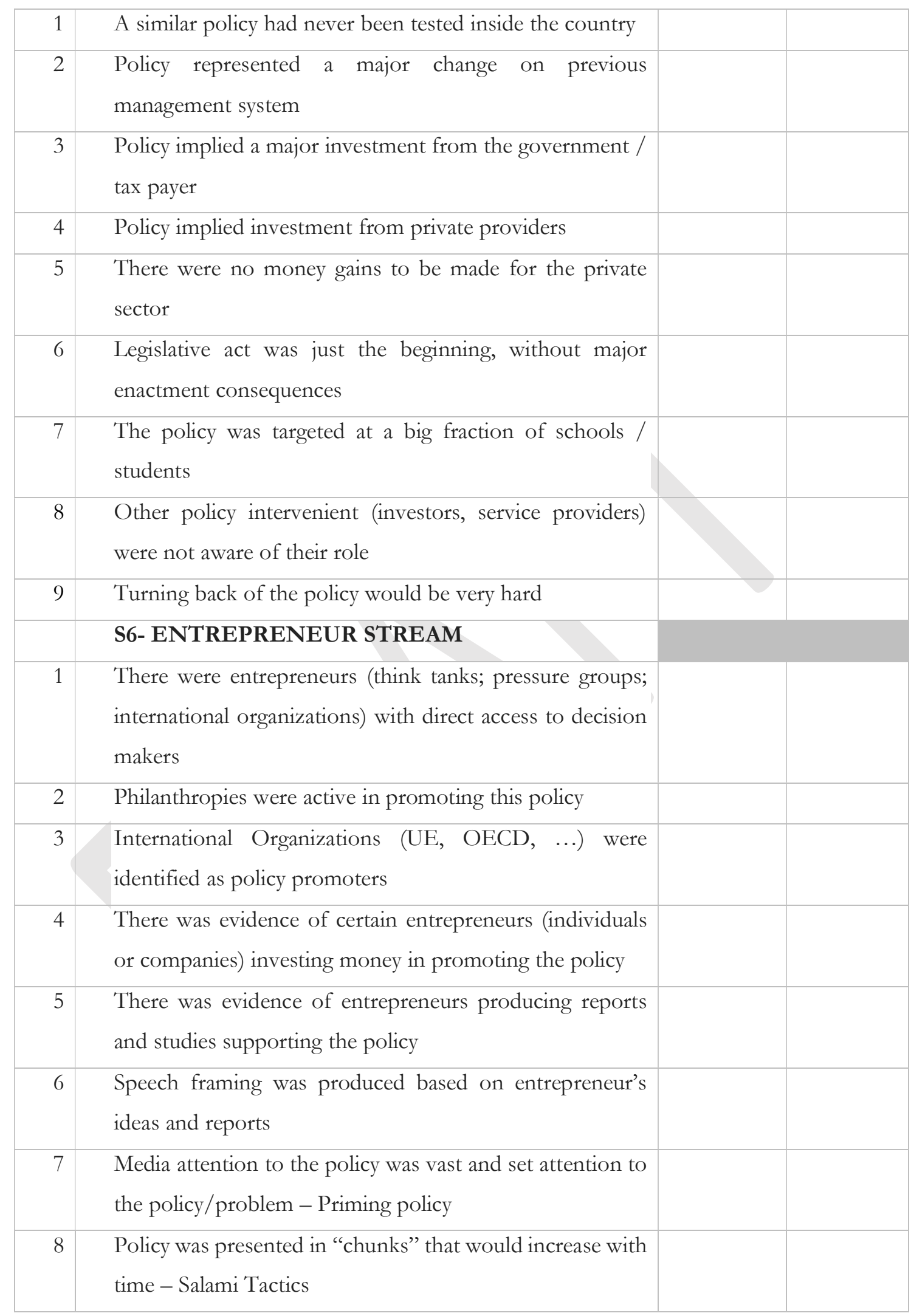


Possible answers were just true or false. Three independent experts answered this set of questions to avoid researcher bias. The mean of these answers was then converted into the model scale and proportionated the required quantitative information to attribute values that could be used to test the above formula. Conversion obeyed to the interval scheme previously determined (Table 2).

Table 2: Conversion scheme from statement mean to model weights

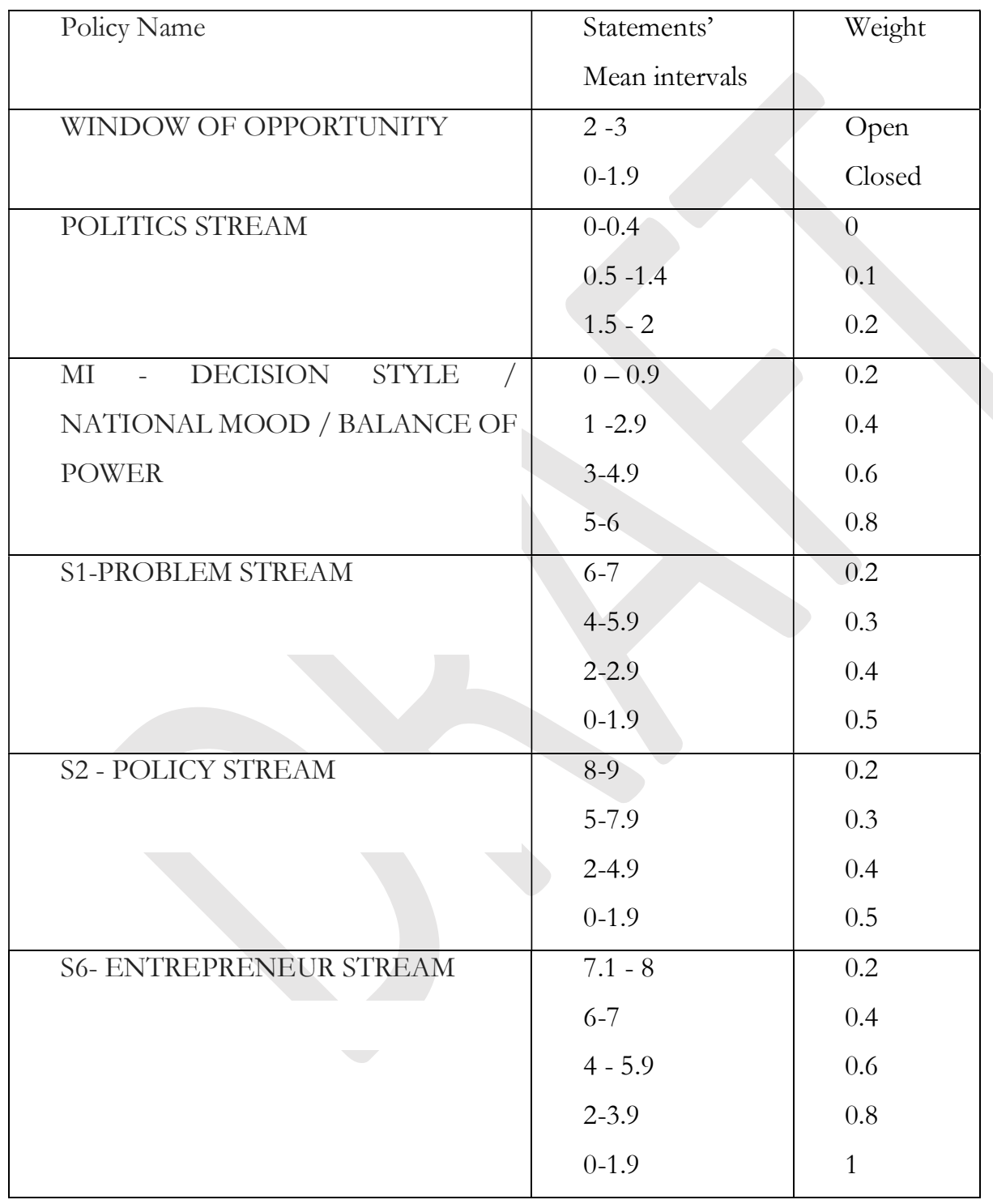

This formula reveals the real balance that is required for policy change to hold and to be enacted. Every stream plays an important role, and it can break at any point. Very weak entrepreneurs, valued at 0.8 will only lead to easy policies, attached to easy problems when the national mood is very favourable and the politics balance is advantageous. In no other 
circumstance can a very weak entrepreneur lead a policy change. Though it is not enough to have a strong entrepreneur, as if they fail to persuade the national mood, or the combination problem/policy is too difficult or the politics are not favourable, policies will also have a higher probability of failing.

Methodological Steps

The methodology used obeys to a very clear set of steps that we followed to achieve the conclusions exposed in relation to ePPPs during the conservative England 1980-1997.

1) Identify the political cycles in the case

2) Identify every policy legislated that falls in the ePPP definition

3) Collect data related to every policy

4) Codify data for each policy according to the codebook

5) Engage in a thick description of the process of decision making and its consequences

6) Summarize the information in the flowchart (Figure 2)

7) Give the description and flowchart to external readers and get them to answer the checklist (table 1) to quantify the streams

8) Calculate the average of the answers for each item, and calculate the for sum each stream creating an index. Transform the index into the scale of the quantitative model (table 2)

9) Verify if the result of quantification by external readers match the policy result, i.e. for a well succeeded policy the equation must be true, and for a policy that did not achieve the desired effect the equation must be false

As the objective of this work is to focus on the process of decision and unveil why radical changes to school administration has been happening in some countries and not in others. As explained by other authors it is not only ideology, nor tradition, nor international pressure, nor any of the other approaches explored above. It is probably a combination of all this that can only happen at very special moments in time, when all the forces (streams) converge in a certain manner.

\section{The failure of Inner City Technology Colleges}

The hypothesis that we are testing is: there will only be a successful implementation of privatisation measures when a window of opportunity opens and the policy is attached to a compatible problem within a favourable political environment. The coupling of the streams happens in the presence of 
policy entrepreneurs who are strong and quick enough to make the streams go through the window, before it closes. In case a policy is legislated before the previous balance is achieved, the implementation will have a smaller probability of success. Success is measured by the number of schools that adopted the proposed policy, and is balance with the objectives initially set by the political actors.

\section{The General Political Environment}

In this paper we are only analysing the first policy towards ePPPs, that happened in England while Margaret Thatcher was the prime minister.

In May 1979, Thatcher's Conservative party is called by the electorate to form government, following a 'winter of discontent', especially with prolonged pay cuts and restrictions. The window for discussing education role and purpose had been opened by the previous government, and the change to a new political cycle made sure it would remain open. The general discussion on education, during the run up for election period, on education gave space for some thinkers and academics to publish their ideas. A series of publications entitled the "black papers", were later used as a pillar for change. The ideas were purely liberal, based on the previous work by Friedman (1955). These was the chance to an 'ever-growing number of right-wing think-tanks with small but interlocking memberships' which 'bombarded' ministers with policy ideas 'ideologically driven by commitment to the market and to privatisation' (Benn \& Chitty, 1996, p. 12).

Margaret Thatcher brings a neoliberal agenda into government, with no hiding of her intentions about opening the economy as well as the welfare system to private initiative. A complete focus on cost reduction, privatisation, and the promotion of new forms of public management. Regarding education, and benefiting from the previous discussions and formulations, her first big concern was to take the power away from Local Education Authorities (LEAs) and bring it to central state. One would dare saying that her real concern was not to get the involvement of private agents, but instead to destroy LEAs that worked very much as unions, concentrating to much bargaining power for her taste. She was criticized within her own party, in a memo written by the influential adviser Oliver Letwin (21 February 1986²) "You were elected to give back to individuals a greater degree of responsibility for their own lives," he wrote. "In education, you have so far failed." He continues by saying that education is still a "Nationalised Industry", though he recognises that such a dramatic move would face very strong opposition from several sectors of society, in a way recognising that social mood was not ripe for this

Despite all these considerations, between 1980 and 1989 some measures to bring private agency into education were taken, continued or perfected during Major's government (Figure 3).

\footnotetext{
${ }^{2}$ http://www.bbc.com/news/uk-30625941
} 


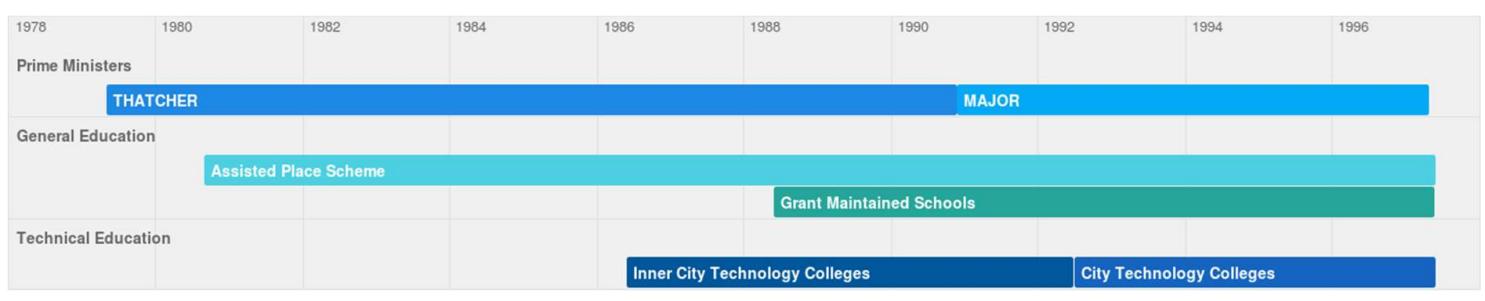

During this period, there were three main policies approved, two of them (Grant Maintained Schools and City Technology Colleges) involving private providers as school managers or investors, and one of them was just sending some students to private schools, while paid by the state. This paper will focus solely on the Inner City Technology Colleges, as it was the first attempt to establish ePPPs in England.

Qualitative analysis

As Sir Keith Joseph became secretary of education in 1982, a supporter of free will, market choice and smaller government. He tries to implement measures that would retract rights from teachers, and they answered with several strikes. This re-enforced the window of opportunity for school choice, and private participants with state education. Middle class, who seek a good education for their children, were looking at teachers as salary seekers, who are not very interested in children wellbeing. Education gets to the top of political agenda, and there is a general feeling that the government needs to do more and different ${ }^{3}$.

Mr. Kenneth Baker substituted him in 1986, who was seen as a humane liberal thinker, capable of clear communication with the media ${ }^{4}$. Few weeks after stepping up he starts repaving the way towards privatization, as he creates the Inner City Technology Colleges (CTC), with the objective of bringing extra diversity into education and better serve the job market.

According to the British Government definition" "(Inner) City Technology Colleges are independent schools in urban areas that are free to go to. They're owned and funded by companies as well as central government (not the local council). They have a particular emphasis on technological and practical skills".

Though this was intended to be a basilar stone in the path to more choice and education market liberalization it is argued that this policy proved to be very unpopular and full of policy design flaws "Examining the CTCs under four headings: choice, selection, control, and content is concluded

\footnotetext{
${ }^{3}$ Parent power is the watchword, The Guardian, May 25, 1987

${ }^{4}$ Baker policies are all puff and no pastry, The Observer, Jun 7, 1987

${ }^{5}$ https://www.gov.uk/types-of-school/city-technology-colleges
} 
that they have failed, in their aim to attract private funding, are unpopular with almost all educational forces outside government, and offer very little that is different from current secondary education" (Dale, 1989, p. 4)

Though this measure was presented as an innovation, it came in the footprint of a curricular revision implemented in certain secondary schools in 1982, known as the TVEI (Technical and Vocational Education Initiative) that had been an initiative of the Department of Employment and was to be interpreted and implemented by LEAs, within regular secondary education. However, TVEI had risen several resistance at the enactment level from parents and teachers, as it looked like a return to Victorian style education (McCulloch, 1989), many schools were slowly establishing partnerships with local industries and trying to adapt parts of teaching to labour market requirements ${ }^{6}$. The big difference of CTCs was that they would surpass LEA and create autonomous institutions just for this purpose, with stronger links to companies via sponsorship.

A hundred of these colleges should open across the country, they had to be partially sponsored by businesses on a 20 to 80 proportion, and the curriculum was to be explicitly technical, the per student cost of such a system would imply a higher spending per pupil than normal local schools. Actually it implied massive amounts of money invested in a small number of schools "The government in fact provided 85 per cent of the foundation costs of the Nottingham CTC, at a cost of £9.05 million, many times its spending on all the other schools in the authority combined" (Dale, 1989, p. 11) LEAs would not have a word to say in this school typology, though they would lose financing proportional to number of students who left for CTCs.

The origins of this policy are hard to trace, and they might have been inspired in Spens Report's $(1938)^{7}$ advocacy of technical high schools, as a way of firstly experimenting with partnerships between private and public sector in education in a controlled scale, affecting only a small sub-section of the population; secondly give technical education a more glamorous chance as a manner of clearing its name of second level education path; and thirdly genuinely contribute for a more competitive British economy, somehow following Germany's tradition. They may also have been imported from the USA new venture technological schemes (Whitty, 1990). As Mr. Baker pointed out himself "success of magnet and other specialist schools in the United States, notably the Bronx High School for Science, in transforming the achievements of inner-city children and acting as "beacons of excellence" to spur surrounding schools to make similar improvements." (Whitty, 1990, p.107). Mr. Baker's fascination with the USA models continued even after the relative lack of success of his model in England ${ }^{8}$.

\footnotetext{
${ }^{6}$ Cuckoos in the nest, The Guardian, Nov 18, 1986

${ }^{7}$ Withdrawn from http://www.educationengland.org.uk/documents/spens/spens1938.html

${ }^{8}$ Baker gives New York school top marks, The Guardian, Sep 22, 1987
} 
This idea came to public for the first time within the policy agenda, in a conference at the House of Lords to discuss the growing youth unemployment issue. In 1986, a meeting organised by Cyril Taylor, at the time the head of a powerful think tank, Centre for Policy Studies (CPS). He held a meeting with 60 businessmen trying to bring a solution to massive youth unemployment ${ }^{9}$. The prime minister and several other elements of the government attended this meeting. One of the problems pointed was the inadequacy of school education to labour market needs, and the policy suggested to solve this state of affairs was the immediate establishment of 100 City Technology Colleges.

The government rushed into this policy without seriously considering its feasibility or reception from the companies and society. The government envisaged the creation of new schools, partially funded by sponsors. In one of the schools created under this policy, Kingswood in Bristol, the fund invested the "required $£ 2 m$; the government handed over the remaining $£ 8 m$ ". The government was to contribute to the initial setting of the school and to its maintenance and operation $\operatorname{costs}^{10}$. The costs of this policy, though significantly high per student, as each school meant new premises, it was not prohibitive, especially because it was only to be applied in inner cities. As with the Assisted Places Scheme the government kept it limited in extension, with a first objective of 20 CTCs which should be later enlarged to 100.

The colleges were to be run by trusts, out of the LEAs control, under the control of the Education Secretary. The curriculum was to focus on science, mathematics, and technology and then they only had to respect half of the core curriculum on humanities, language, and arts. The emphasis should also go to self-discipline and attitude, as the objective was to produce students with businesslike skills. The governing body of schools would have autonomy to negotiate salaries and hire teachers directly, and would be able to manage students at their will, including selection by ability and/or parent compromise on long term education goals. The companies who sponsored could design the governing body as well ${ }^{11}$. The schools should receive between 750 and 1000 students each, and open in geographical areas identified by the government.

According to the original 1986 plan these schools should be in operation by 1990, as they were to be built from scratch. In 1989, Mr Baker made a speech where he stated that the objectives were simple "They (CTC) will raise the sights of teachers, pupils and parents in our cities where expectations can be needlessly low. They will do so by increasing choice, injecting competition, and helping to raise standards generally" (Baker, 1989).

The problems attached to this policy come in the same line as privatization of education traditionally couples with: more choice, more diversity in education, different paths for different

\footnotetext{
${ }^{9}$ https://en.wikipedia.org/wiki/Cyril_Taylor\#cite_note-22

${ }^{10} \mathrm{http}: / /$ www.educationengland.org.uk/history/chapter08.html

11 Industry is wary of funding plea for city schools ,The Guardian, Oct 15, 1986
} 
capabilities and more specific to this policy the problems of inner cities' under-achievers. It is pointed by Dale (1989) that this policy was not adding any novelty in pedagogy or content. Therefore, the importance of the measure was really to set an agenda for choice, though this specific policy would only provide choice for a very limited number of families. It would anyhow be choice, as CTC were drawn to be free to the final user. As argued by Dale $(1989$, p. 17) it was "a highly political programme which is emblematic of thoroughgoing Thatcherism".

The entrepreneurs of this new scheme, of bringing private providers as school sponsors, in exchange for the management of schools and liberty to set their own curriculum, teacher, and general organization strategy, were very much the same as for Assisted Places Scheme. Within the conservative party most advisors were favourable, except for the previous education secretary, Sir Keith Joseph, who in 1985, while still occupying the chair, had declared it practically unworkable. It also had the support of businesses with close political connections to the Thatcher government. Actually, as the first colleges were on the verge of opening Mr. Baker (1989) was extremely optimistic regarding the generosity of businesses, and the willing of their managers to contribute with knowledge to an area that was basically unknown to most of them.

Sir Cyril Taylor became chairman of CTC Trust, a body created to be in charge of administering CTCs implementation. He was a businessman with close interest in education, who had founded in 1964 the American Institute for Foreign Study (AIFS) created to develop the interchange of students between England and America. In 1971, he had also been the founder of Richmond University, an American University in London and finally he was appointed chairman of Centre for Policy Studies, Thatcher's think tank. Following his proximity with the government he was appointed between 1987 and 2007, as Education Adviser to ten successive Secretaries of State for Education on the Specialist Schools and later on Academies. Entrepreneurs to this policy were essentially politicians and educators; the idea did not come from industry and they had to be persuaded into the scheme. Only small companies who needed favours from the government were enthusiastic with these project, even though giving a personal or company name to the school was part of the packet. The lack of private sponsors can be seen as a weak point in all these scheme, leading to very few effective implementations. Though the politicians managed to draw a speech to persuade parts of the society, and to appeal to some parents, they were not very effective in framing a proper speech to persuade companies to donate their money to such a venture. As Francis Beckett ${ }^{12}$ puts it "Margaret Thatcher herself had to be called in to try to twist arms, personally telephoning the chairman of $B P$, who turned her down, even though his company was at the time spending $£ 9 m$ on community activities, $£ 1.9 m$ of it on education".

${ }^{12}$ What goes around ..., Guardian, Tuesday 3 October 2006 
Some of the early sponsors were really supporting this idea for the sake of educating the adults of tomorrow "who understand the commercial culture ... understand the profit motivation. understand about personal aspirations for personal success" (radio interview by Stanley Kalms, Chairman of Dixons, retrieved from (Gewirtz, Whitty, \& Edwards, 1992, p. 216)). Initially it seemed that the business community was backing the government on this, but few days after announcement the industry showed real concerns for this plan and an enormous lack of enthusiasm, and uneasiness about the feasibility of the whole scheme ${ }^{13}$.

The media gave a relatively large cover to the issue, the guardian archives show 80 results for "City Technology Colleges" in the years 1986 and 1987, which represented 10\% of the articles in education policy, regarding the secretary of state. If we consider the period until the policy is discontinue by 1992, we could find 306 articles at the Guardian and the Observer, meaning that this subject had a reasonable cover from the media. The first article popped up in October 1986 to announce the launching of this idea by Kenneth Baker, the new Secretary of Education. Though some articles were to expose the negative points of the scheme, the biggest part tends to be merely informative on the policy design, supporters, and oppositions.

The scheme was opposed by the Labour party, “(...) spokesperson to protest that the government's original intention of setting up public schools with private money had now changed to setting up private schools with public money" (Whitty, 1990, p. 108). Some other people from different levels of society have also came forward with their opposing views "John McLoed of the Association of Metropolitan Authorities (AMA) argued that this was an initiative which local authorities did not need to frustrate: it frustrated itself through its own poor conception and inadequate preparation'" (Whitty, 1990, p. 110).

The lines of criticism were similar to every policy that calls into bringing private provision to public services: money to finance private sectors instead of helping public facilities in need; more selection and less equality of opportunities, as these schools are entitled to select their students; nonfeasible, disorganised policies that put at risk children, families and other schools. It was also highly criticised by being another policy drawn to give extra-treatment to an incredibly small number of children, which would add nothing to the system as a whole ${ }^{14}$. Another concern was that the extra investment on these schools would dry resources from the normal public system, though Mr. Baker said that this was new money he had negotiated with the finance minister ${ }^{15}$.

\footnotetext{
${ }^{13}$ Industry is wary of funding plea for city schools ,The Guardian, Oct 15, 1986

${ }^{14}$ Inner city colleges launched by Baker, The Guardian, Oct 8, 1986

15 "Baker drops heavy hint on student loans", and "Baker finds extra cash to shore up education", The Guardian, Oct 9, 1986
} 
LEAs were also opposing this scheme and presented their concerns on church schools and other under-financed schools to be forced into selling their facilities to CTCS. AMA (Association of Metropolitan Authorities) ran a survey where it showed clearly that most LEAs were opposing CTCS specially because there had been no thought on the effect of such new schools on the planning and managing of local secondary offer, at the time mostly in the hands of LEAs (McLeod, 1988). The emergence of a CTC in any inner city would certainly compromise the survival of at least one of the comprehensives already running, if not all of them, by the simple reason that adding 1000 new places to any area would represent a high share of the students available ${ }^{16}$.

While the government argued that this initiative would be popular with parents in the CTC designed areas, some parents were really concerned about the change into CTC status as technical education was not a well-established concept (McCulloch, 1989), parent resistance was also a source that was on the base of the very limited implementation of CTC colleges.

The biggest share of criticism came later, as the objective of 20 CTCs by 1990 was far from being achieved, and companies were using the scheme to clear their bad images, as was the case of British American Tobacco's money accepted in Middlesbrough CTC ${ }^{17}$. Some other scandals came about, and even the government had to recognise that things had not came as planned, as in 1992 only 15 CTCs were working around the country.

To reformulate the policy from its inside, and as an answer to major opposition from LEAs, and lack of enthusiasm by sponsors, the think tank Institute of Economic Affairs published a booklet arguing for the establishment of magnet schools within the state system. This schools would guarantee competition of LEAs to the emerging CTCS, calling attention to the fact that this move results from the insertion of competition as a trigger of development ${ }^{18}$. As election approached other think tanks and associations published reports and studies on the advantages of ePPPs, as was the case of Hillgate Group who published a manifesto entitled "whose schools" asking for the scrapping of LEAs and more partnerships with private providers. Despite the fact that the Conservative Party was elected for a third mandate, CTCs were not successful and they were put to sleep, as the window of opportunity closed with the resignation of Margaret Thatcher, in November 1990.

The feedback to this measure proved that not everyone was prepared at the time to embrace this typology of ePPP. Business and government were not ready to give hands to invest and run new school projects. So, this apparent failure went back into the policies stream to further improve the instrument and revise its implementation process.

${ }^{16}$ Cuckoos in the nest, The Guardian, Nov 18, 1986

${ }^{17}$ https://www.theguardian.com/education/2006/oct/03/schools.uk

${ }^{18}$ Economists call for schools to compete with city colleges, The Guardian, Oct 5, 1987 
Figure 4: Flowchart of the decision process for Inner City Technology colleges

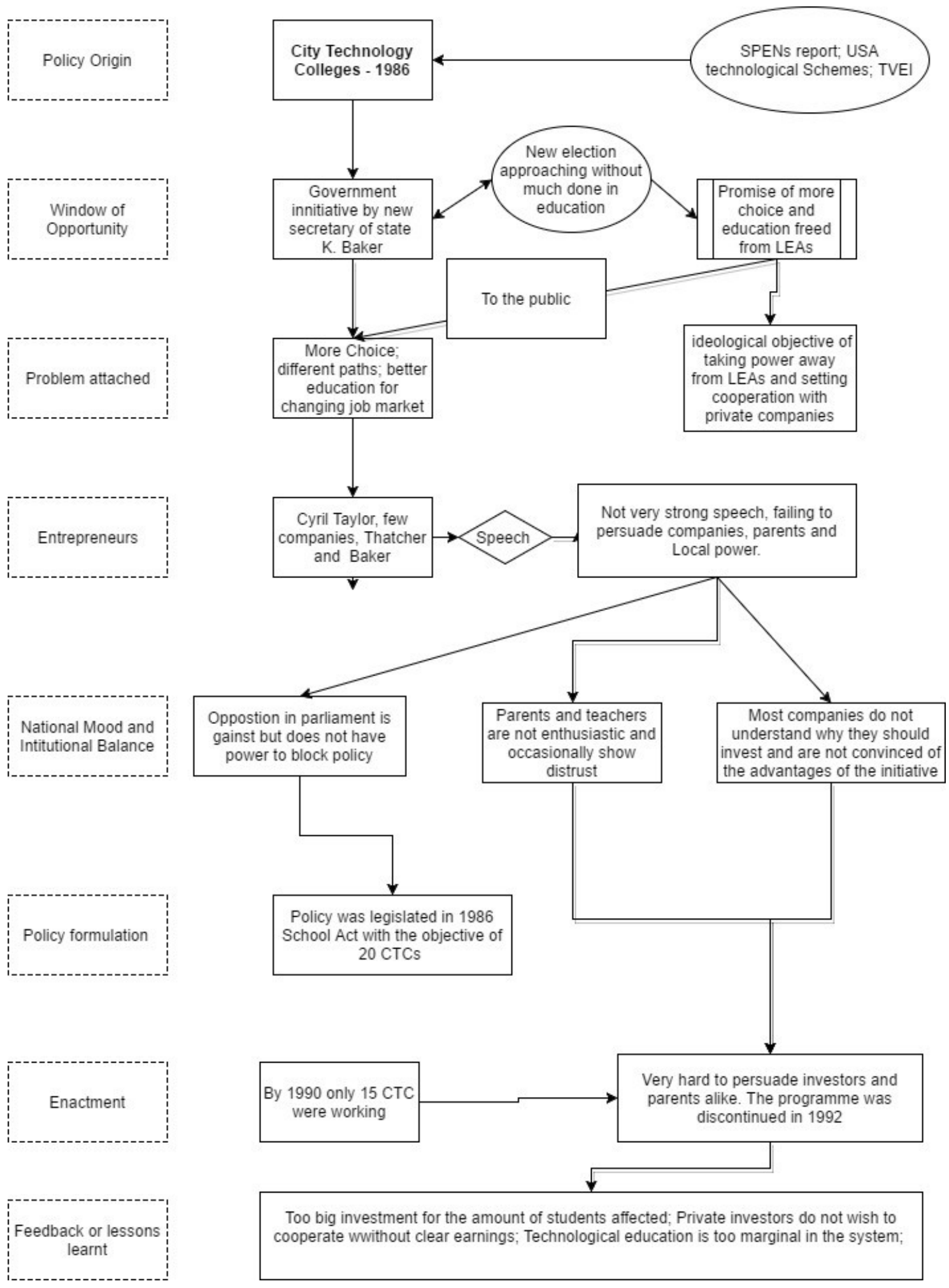

The flowchart (Figure 4.) illustrates the fragilities of this policy as business investors were not involved in the design of the policy, but were instead taken for granted. There was no special speech or preparation period to get these important actors ready. Though the measure went through the 
parliament, and was legislated, this was far from being sufficient to guarantee enactment. The not very ambitious objective of 20 CTCs was not achieved and the difficulties with the private companies worked as a lesson to be incorporated in the next policy.

Quantitative Analysis

\begin{tabular}{|c|c|c|c|}
\hline & Inner City Technology Colleges & True & Model \\
\hline & WINDOW OF OPPORTUNITY & 3 & Open \\
\hline 1 & $\begin{array}{l}\text { The window opened in political stream (Ex. } \\
\text { Elections) }\end{array}$ & 1 & \\
\hline 2 & $\begin{array}{l}\text { There was no reason for a sudden close of the } \\
\text { window (ex. An accident of political upheaval) }\end{array}$ & 1 & \\
\hline 3 & $\begin{array}{l}\text { The government was fast in policy approval (no } \\
\text { more than } 1 \text { year since the policy first emerged) }\end{array}$ & 1 & \\
\hline & POLITICS STREAM & 1 & 0.1 \\
\hline 1 & The government was predominantly conservative & 1 & $\mathcal{H}$ \\
\hline 2 & The main opposition party did not oppose policy & 0 & \\
\hline & $\begin{array}{l}\text { MI - NATIONAL MOOD AND } \\
\text { INSTITUTIONAL BALANCE }\end{array}$ & 3 & 0.6 \\
\hline 1 & Parents were generally in favour & 0 & \\
\hline 2 & $\begin{array}{l}\text { Teachers, Head teachers from state schools were } \\
\text { in favour }\end{array}$ & 0 & \\
\hline 3 & $\begin{array}{l}\text { Teacher Unions did not organise major strikes or } \\
\text { parades }\end{array}$ & 1 & \\
\hline 4 & Local/Regional authorities were favourable & 0 & \\
\hline 5 & No major opposition on the press & 1 & \\
\hline 6 & $\begin{array}{l}\text { Opposition surged mainly from marginal actors } \\
\text { (intellectuals, small pressure groups) }\end{array}$ & 1 & \\
\hline & S1-PROBLEM STREAM & 2 & 0.4 \\
\hline 1 & $\begin{array}{l}\text { There was more than one problem attached to the } \\
\text { policy }\end{array}$ & 1 & \\
\hline 2 & $\begin{array}{l}\text { There was an event calling attention to the } \\
\text { problem }\end{array}$ & 0 & \\
\hline 3 & The problem was quantified & 0 & \\
\hline 4 & The problem(s) was well defined & 1 & \\
\hline
\end{tabular}




\begin{tabular}{|c|c|c|c|}
\hline 5 & $\begin{array}{l}\text { The problem could be recognised as affecting } \\
\text { more than } 25 \% \text { of students }\end{array}$ & 0 & \\
\hline 6 & $\begin{array}{l}\text { The problem affected several social and } \\
\text { economic classes }\end{array}$ & 0 & \\
\hline \multirow[t]{2}{*}{7} & There was an urgent problem to be solved & 0 & \\
\hline & S2 - POLICY STREAM & 7 & 0.3 \\
\hline 1 & $\begin{array}{l}\text { A similar policy had never been tested inside the } \\
\text { country }\end{array}$ & 1 & \\
\hline 2 & $\begin{array}{l}\text { Policy represented a major change on previous } \\
\text { management system }\end{array}$ & 1 & \\
\hline 3 & $\begin{array}{l}\text { Policy implied a major investment from the } \\
\text { government / tax payer }\end{array}$ & 1 & \\
\hline 4 & Policy implied investment from private providers & 1 & \\
\hline 5 & $\begin{array}{l}\text { There were no money gains to be made for the } \\
\text { private sector }\end{array}$ & 0 & \\
\hline 6 & $\begin{array}{l}\text { Legislative act was just the beginning, without } \\
\text { major enactment consequences }\end{array}$ & 1 & \\
\hline 7 & $\begin{array}{l}\text { The policy was targeted at a big fraction of } \\
\text { schools / students }\end{array}$ & 0 & \\
\hline 8 & $\begin{array}{l}\text { Other policy intervenient (investors, service } \\
\text { providers) were not aware of their role }\end{array}$ & 1 & \\
\hline \multirow[t]{2}{*}{9} & Turning back of the policy would be very hard & 1 & \\
\hline & S6- ENTREPRENEUR STREAM & 3 & 0.8 \\
\hline 1 & $\begin{array}{l}\text { There were entrepreneurs (think tanks; pressure } \\
\text { groups; international organizations) with direct } \\
\text { access to decision makers }\end{array}$ & 1 & \\
\hline 2 & $\begin{array}{l}\text { Philanthropies were active in promoting this } \\
\text { policy }\end{array}$ & 0 & \\
\hline 3 & $\begin{array}{l}\text { International Organizations (UE, OECD, ...) } \\
\text { were identified as policy promoters }\end{array}$ & 0 & \\
\hline 4 & $\begin{array}{l}\text { There was evidence of certain entrepreneurs } \\
\text { (individuals or companies) investing money in } \\
\text { promoting the policy }\end{array}$ & 0 & \\
\hline
\end{tabular}




\begin{tabular}{|l|l|l|l|}
\hline 5 & $\begin{array}{l}\text { There was evidence of entrepreneurs producing } \\
\text { reports and studies supporting the policy }\end{array}$ & 1 \\
\hline 6 & $\begin{array}{l}\text { Speech framing was produced based on } \\
\text { entrepreneur's ideas and reports }\end{array}$ & 1 \\
\hline 7 & $\begin{array}{l}\text { Media attention to the policy was vast and set } \\
\text { attention to the policy/problem - Priming policy }\end{array}$ & 0 \\
\hline 8 & $\begin{array}{l}\text { Policy was presented in "chunks" that would } \\
\text { increase with time - Salami Tactics }\end{array}$ & 0 \\
\hline
\end{tabular}

Entrepreneurial $\leq\langle(($ Problem + policy $) *$ decision Style $)+($ Politics $)\rangle \mid($ WINDOW OPEN $)$

$$
\begin{gathered}
0.8 \leq(0.4+0.3) *(0.6)+0.1] \mid \text { OPEN } \\
0.8 \leq 0.52 \mid \text { OPEN }- \text { FALSE }
\end{gathered}
$$

The numerical model is in line with the no implementation of CTC. We can see that the entrepreneurs were weak for a far too difficult policy, in its technical feasibility and value acceptability. The private intervenients were not sufficiently mobilized and by the time they were called into action, most did not understand the advantage of a big investment to unclear gains. On the other side, the society was not very motivated, though there was no major opposition once this was a very small and enclosed measure designed to affect a very small number of students, of very clear profiles - inner cities deprived areas.

This policy as a standalone strategy was doomed from its conception, though seen from a distance of 30 years it seems clearly just another piece of the more complex puzzle of getting private agents as the main education providers. "Policies can rarely be said to have a clear time point at which they were 'initiated' and policy is also rarely initiated purely by politicians then developed purely by civil servants" (Exley, 2014, p. 2).

As the system started to show its fragilities, in 1988 the government had already prepared a followup strategy, determined to not let it go. Bringing private enterprise closer to education was deep in the government's mind. This time the idea was grant maintained schools.

\section{Conclusions}

The main goal of our research was to propose an operationalization mode for research using the Multiple Streams Approach on its qualitative and quantitative potential. We then set in the analysis of a public policy linked to the privatization of education, tried in England in 1986-1990.

We showed that Multiple Streams Approach, being a multi-variable model is well applied to study the probability of policy implementation (or lack of it) at the moment of policy approval. The basilar idea that we intended to explore was that when there is no balance in between the streams at the 
moment of policy legislation, even in the presence of a strong neoliberal government and within a propitious institutional moment, the possibility of successful implementation is low.

Multiple Streams Approach is an interesting model, though not very intuitive on its implementation. We devised a method that has a strong qualitative analysis, based on multiple sources. The starting point of this analysis is the collection and interpretation of as much information as possible to unveil the decision process on its several components, summed up in the streams. The codification of the information will result in a thick description of events and actors.

The qualitative analysis can then be transposed into a quantitative model, where indexes are built by reflecting if certain statements are true or false, as a mode of attributing weights to the streams. The statements were developed having in mind our object of study, though we think these statements can be adapted to fit other policy problems. Once all the weights have been determined it becomes clear that only in the presence of ripe streams that are ready to be coupled by an adequate policy entrepreneur, does a certain measure increase its probability of desired implementation.

The usage of this type of methodologies by policy makers could reduce the amount of policy inefficiency. Policy changes would only get legislated when the several actors and social constraints were ready for implementation, reducing the tiredness of the society towards constant policy failure.

We have then illustrated our model with the failure of Inner City Technology Colleges (England), the first measure towards the privatization of education in England, which was approved in a very favourable ideological and institutional moment, though the schools, investors and parents refused it. We use the model to prove that lack of stream ripeness originated the unsuccessful implementation. 


\section{Bibliography}

Alexiadou, N., Fink-Hafner, D., \& Lange, B. (2016). Education Policy Convergence through the Open Method of Coordination : theoretical reflections and implementation in 'old ' and ' new' national contexts. European Educational Research Journal, 9(3), 345-358.

Baker, K. (1989). City technology colleges. Education + Training, 31(3). http://doi.org/10.1108/eb055149

Ball, S. J. (2012). Global Education Inc: New Policy Networks and the Neo-Liberal Imaginary. London, UK: Routledge.

Benn, C., \& Chitty, C. (1996). Is comprehensive Educatio Alive and Well or Struggling to survive? London, UK: David Fulton Publishers.

Chattopadhyay, S. (2012). Education and Economics (1st ed.). Oxford University Press. http://doi.org/10.1093/acprof:oso/9780198082255.001.0001

Cohen, M. D., March, J. G., \& Olsen, J. P. (1972). A garbage Can Model of Organizational Choice. Administrative Science Quarterly, 17(1), 1-25.

Dale, R. (1989). The Thatcherite project in education: the case of the City Technology Colleges. Critical Social Policy, 9(27), 4-19. http://doi.org/10.1177/026101838900902701

Exley, S., Braun, A., \& Ball, S. (2011). Global education policy: networks and flows. Critical Studies in Education. http://doi.org/10.1080/17508487.2011.604079

Gewirtz, S., Whitty, G., \& Edwards, T. (1992). City technology Colleges: Schooling for the Thatcher generation? British Journal of Educational Studies, 40(3), 207-217. http://doi.org/10.1080/00071005.1992.9973926

Howlett, M., McConell, A., \& Perl, A. (2013). Reconciling Streams and Cycles. In Political Studies Association Annual Conference (pp. 1-34).

Jones, M. D. M., Peterson, H. H. L. H., Pierce, J. J. J., Herweg, N., Bernal, A., Lamberta Raney, H., \& Zahariadis, N. (2016). A River Runs Through It: A Multiple Streams Meta-Review. Policy Studies Journal, 44(1), 13-36. http://doi.org/10.1111/psj.12115

Kingdon, J. W., \& Kingdom, J. (1984). Agendas, alternatives and public policies. Boston: Little Brown and Company. 
Klitgaard, M. B. (2007). Do Welfare State Regimes Determine Public Sector Reforms? Choice Reforms in American, Swedish and German Schools. Scandinavian Political Studies, 30(4), 444-468. http://doi.org/10.1111/j.1467-9477.2007.00188.x

Klitgaard, M. B. (2010). Veto-points and politics of introducing school vouchers in United States and Sweden. In A. Jacobi, K. Matens, \& K. D. Wolf (Eds.), Education in Political Science: Discovering a negleted field. Oxon: Routledge.

Lasswell, H. D. (1956). The Decision Process: Seven Categories of Functional Analysis. Maryland: University of Maryland.

Laude, H. (1991). Education, Democracy and the Economy. British Journal of Sociology of Education, 12(4), 417-431.

Mangset, P., Kleppe, B., \& Røyseng, S. (2013). Envisaging new educational provision: innovative organisation in the age of New Modernism. The Journal of Arts Management, Law, and Society, 42(4), 156-175. http://doi.org/10.1080/13596748.2011.575260

McCulloch, G. (1989). City Technology Colleges: An Old Choice of School? British Journal of Educational Studies, 37(1), 30-43. http://doi.org/10.1080/00071005.1989.9973795

McLeod, J. (1988). City technology colleges: A study of the character and progress of an educational reform. Local Government Studies, 14(1), 75-82.

http://doi.org/10.1080/03003938808433389

Peters, B. G. (2002). Governance: A garbage Can Perpective. Reihe Politikwissenschaft Political Series, 84 .

Robertson, S. L., \& Verger, A. (2012). Governing Education Through Public Private Partnerships. Centre for Globalisation, Education and Societies. Bristol.

Teodorovic, J. (2008). Why education policies fail: Multiple streams model of policymaking. Zbornik Instituta Za Pedagoska Istrazivanja, 40(1), 22-36. http://doi.org/10.2298/ZIPI0801022T

Thelen, K. A. (2004). How institutions evolve. Insights from comparative historical analysis. Cambridge University Press. http://doi.org/10.1017/CBO9780511803963.007

Verger, A., BonaL, X., \& Zancajo, A. (2016). What Are the Role and Impact of Public-Private Partnerships in Education? A Realist Evaluation of the Chilean Education Quasi-Market. Comparative Education Review. http://doi.org/10.1086/685557 
West, A. (2014). Academies in England and independent schools ( fristående skolor ) in Sweden: policy, privatisation, access and segregation. Research Papers in Education, 29(3), 330-350. http://doi.org/10.1080/02671522.2014.885732

West, A., \& Bailey, E. (2013). The Development of the Academies Programme: 'Privatising' School-Based Education in England 1986-2013. British Journal of Educational Studies, 61(July 2015), 137-159. http://doi.org/10.1080/00071005.2013.789480

Whitty, G. (1990). Creeping Privatization And Its Implications For Schooling In The Inner City. The Urban Review, 22(2).

Zahariadis, N. (1995). Markets, States and Public Policy (1st ed.). Michigan: The University of Michigan Press.

Zahariadis, N. (2003). Ambiguity and Choice in Public Policy. Georgetown: Georgetown University Press.

Zahariadis, N., \& Exadaktylos, T. (2016). Policies that Succeed and Programs that Fail: Ambiguity, Conflict, and Crisis in Greek Higher Education. Policy Studies Journal, 44(1), 5982. http://doi.org/10.1111/psj.12129 